DOI: $10.15193 /$ zntj/2019/120/294

\title{
WIOLETA CHAJĘCKA-WIERZCHOWSKA, ANNA ZADERNOWSKA \\ BAKTERIE FERMENTACJI MLEKOWEJ W TYM SZCZEPY PROBIOTYCZNE JAKO REZERWUAR GENÓW OPORNOŚCI NA ANTYBIOTYKI
}

\begin{abstract}
Streszczenie
Antybiotykooporność stała się jednym z głównych problemów dotyczących bezpieczeństwa zdrowia publicznego. Przez długi czas zjawisko oporności bakterii na antybiotyki wiązano jedynie z presją selekcyjną w środowisku szpitalnym. Dopiero wzrastająca wiedza na temat genetycznych podstaw oporności oraz mechanizmów, jakie towarzyszą jej przekazywaniu, ukierunkowała badaczy na kompleksowe spojrzenie w jej epidemiologię. Bakterie fermentacji mlekowej (LAB) zostały uznane za bezpieczne ze statusem GRAS (Generally Recognized as Safe) i QPS (Qualified Presumption of Safety), nadanym przez władze FDA i EFSA. Jednakże badania ostatnich lat wskazują, że zarówno wśród szczepów wchodzących w skład kultur starterowych, jak i probiotycznych, występują także oporne na antybiotyki, które mogą przekazać tę oporność innym drobnoustrojom. Jeśli oporność ta jest cechą wrodzoną, związaną z informacją zakodowaną w chromosomie, nie ma powodu do niepokoju. Niestety coraz częściej obserwowane są szczepy z opornością tzw. nabytą na skutek mutacji punktowych lub transferu genów. Oba te zjawiska prowadzą w konsekwencji do trwałego dziedziczenia oporności, a także do jej rozprzestrzeniania drogą transferu horyzontalnego (HGT). Wskutek transferu w komórkach pojawiają się nowe geny oporności, przenoszone na ruchomych elementach genetycznych, takich jak plazmidy, transpozony, sekwencje insercyjne. Coraz częściej pojawiają się niepokojące doniesienia wskazujące, że LAB, w tym szczepy probiotyczne, wykazują oporność nabytą na coraz więcej grup antybiotyków, zwłaszcza na tetracykliny, makrolidy, glikopeptydy czy amfenikole. U wielu z tych szczepów stwierdza się obecność determinant oporności na ruchomych elementach genetycznych, a także potwierdza się ich zdolność do przekazywania genów na drodze HGT do innych bakterii, w tym patogennych.
\end{abstract}

Słowa kluczowe: antybiotykooporność, LAB, probiotyki, horyzontalny transfer genów

\section{Wprowadzenie}

Światowa Organizacja Zdrowia (WHO) podkreśliła, że problem wzrastającej antybiotykooporności drobnoustrojów jest na tyle poważny, że zagraża osiągnięciom

Dr inż. W. Chajęcka-Wierzchowska, dr hab. inż. A. Zadernowska, prof. nadzw., Katedra Mikrobiologii Przemystowej i Żywności, Wydz. Nauki o Żywności, Uniwersytet Warmińsko-Mazurski w Olsztynie, Pl. Cieszyński 1, 10-719 Olsztyn. Kontakt: wioleta.chajecka@uwm.edu.pl 
współczesnej medycyny, a infekcje spowodowane bakteriami opornymi na działanie antybiotyków są obecnie jednym z najważniejszych problemów zdrowotnych na świecie. Doniesienia ostatnich lat wskazują, że problem występowania szczepów opornych na antybiotyki dotyczy nie tylko środowiska szpitalnego, ale także izolatów z innych źródeł, w tym coraz częściej obserwowany jest u szczepów izolowanych z żywności. Niemniej jednak badacze skupiają się na antybiotykooporności bakterii chorobotwórczych i oportunistycznych występujących w żywności niż bakterii fermentacji mlekowej (LAB - ang. Lactic Acid Bacteria), które mają długą historię stosowania w przemyśle spożywczym. Używane są jako kultury starterowe, kultury ochronne oraz probiotyczne. Jest to duża, heterogenna grupa drobnoustrojów, do której należą pałeczki z rodzajów Lactobacillus, Bifidobacterium, Carnobacterium oraz ziarniaki Lactococcus, Leuconostoc, Pediococcus, Streptococcus i Enterococcus.

Dla kilku rodzajów bakterii fermentacji mlekowej Europejski Urząd ds. Bezpieczeństwa Żywności (EFSA) zaproponował wartości graniczne (ang. breakpoint) określające wartość MIC (ang. minimal inhibitory concentration) lub wielkość strefy zahamowania wokół krążka z antybiotykiem, które kwalifikują szczep do kategorii: wrażliwy, średnio wrażliwy lub oporny. W związku z tym należałoby zwracać szczególną uwagę na oporność na antybiotyki wskazane przez EFSA, aby ocenić bezpieczeństwo i skuteczność nie tylko nowych gatunków i szczepów przed wprowadzeniem ich do produktów spożywczych, ale i zweryfikować od lat stosowane w przemyśle kultury starterowe i probiotyczne. Najważniejszym czynnikiem decydującym o kwestii bezpieczeństwa danego szczepu jest możliwość przeniesienia oporności, a nie samo jej występowanie. Konieczne jest zatem określenie, czy geny oporności znajdują się na mobilnych elementach genetycznych, czy też jest to cecha wrodzona. Naturalna oporność LAB i probiotyków na antybiotyki sama w sobie nie jest niebezpieczna, a wręcz pożądana. Zagrożeniem może stać się tylko wtedy, gdy jest możliwa do przeniesienia.

Większość probiotyków jest wprowadzana do organizmu konsumenta w dużych ilościach, zatem obecność determinant oporności na antybiotyki w ich genomie musi być systematycznie badana [33]. Aby zapobiec niepożądanemu przenoszeniu oporności do mikroflory endogennej, probiotyki nie powinny charakteryzować się opornością nabytą. Oporność nabyta związana jest najczęściej ze zmianami w genomie jako skutek mutacji punktowych (losowych), które są następstwem błędów w sekwencji nukleotydowej materiału genetycznego lub mogą być wynikiem nabywania genu albo zespołów genów determinujących oporność na antybiotyki od innych bakterii opornych. To drugie zjawisko zachodzi znacznie częściej, natomiast oba prowadzą w konsekwencji do trwałego dziedziczenia oporności, a także do jej rozprzestrzeniania drogą transferu horyzontalnego [45]. Na skutek horyzontalnego transferu genów w komórkach pojawiają się nowe geny oporności przenoszone na ruchomych elementach genetycznych, jak plazmidy, transpozony lub sekwencje insercyjne. Niejednokrotnie prowadzi to do 
powstania tzw. szczepów wieloopornych (MDR - ang. Multi Drug Resistance), czyli wykazujących niewrażliwość na co najmniej jeden antybiotyk z trzech lub więcej klas, aktywnych wobec danego gatunku drobnoustrojów. Pojawianiu się szczepów wieloopornych sprzyja jednoczesne kodowanie kilku różnych genów oporności na tym samym elemencie genetycznym.

\section{Mechanizm horyzontalnego transferu genów}

Narastająca oporność LAB na antybiotyki wiązana jest m.in. z wykształceniem przez nie efektywnych mechanizmów transferu genów. LAB wykazują niezwykły potencjał w wymianie materiału genetycznego pomiędzy sobą, jak i z innymi gatunkami [28]. Stanowią one mikroflorę żywności i równocześnie wykazują zdolność do przeżywania w dolnych odcinkach przewodu pokarmowego, co powoduje, że mają kontakt $\mathrm{z}$ wieloma rodzajami bakterii, zatem mają warunki, aby przekazywać im własny materiał genetyczny. W przekazywaniu genów biorą udział ruchome elementy genetyczne, które mogą być transferowane pomiędzy różnymi gatunkami, a nawet rodzajami bakterii Gram-dodatnich i Gram-ujemnych [11]. Horyzontalny transfer genów (HGT) pozwala bakteriom na szybkie nabywanie kompleksu nowych cech i jest kluczowym elementem ich ewolucji. Transfer genów LAB najczęściej odbywa się w wyniku koniugacji oraz transdukcji (rys. 1).

Koniugacja jest procesem, podczas którego element koniugacyjny (transpozon lub plazmid) jest przenoszony pomiędzy bakteriami podczas bezpośredniego kontaktu w procesie semikonserwatywnej replikacji. Najbardziej powszechnym mechanizmem horyzontalnego transferu genów jest koniugacja z udziałem plazmidów. Plazmidy to najczęściej koliste, samoreplikujące się cząsteczki DNA. W LAB wyodrębniono plazmidy koniugacyjne, które kodują wszystkie niezbędne do mobilizacji białka oraz plazmidy niekoniugacyjne. Wśród koniugacyjnych wyodrębniono trzy klasy plazmidów zdolnych do replikacji: koliste, Inc18 oraz zależne od feromonów [21]. W LAB najczęściej stwierdzanymi są plazmidy o szerokim zakresie gospodarzy: pAM $\beta 1$, pIP501 i pVA797:Tn917, których horyzontalne przenoszenie między drobnoustrojami przyczynia się do rozprzestrzeniania się oporności [23]. Można tu wymienić m.in. plazmid pMD5057 niosący geny oporności na tetracykliny, plazmid pLME300 L. plantarum związany w opornością na erytromycynę i streptograminę A, którego obecność stwierdzono w L. fermentum oraz plazmid pRE25 naturalnie występujący w Enterococcus faecalis, ale występujący też wśród szczepów Lactococcus lactis, kodujący oporność na erytromycynę i chloramfenikol $[15,34]$. Wśród LAB szczepy należące do rodzaju Lactobacillus częściej wymieniane są jako donory, a szczepy Lactococcus jako akceptory plazmidów niosących oporność na antybiotyki. 


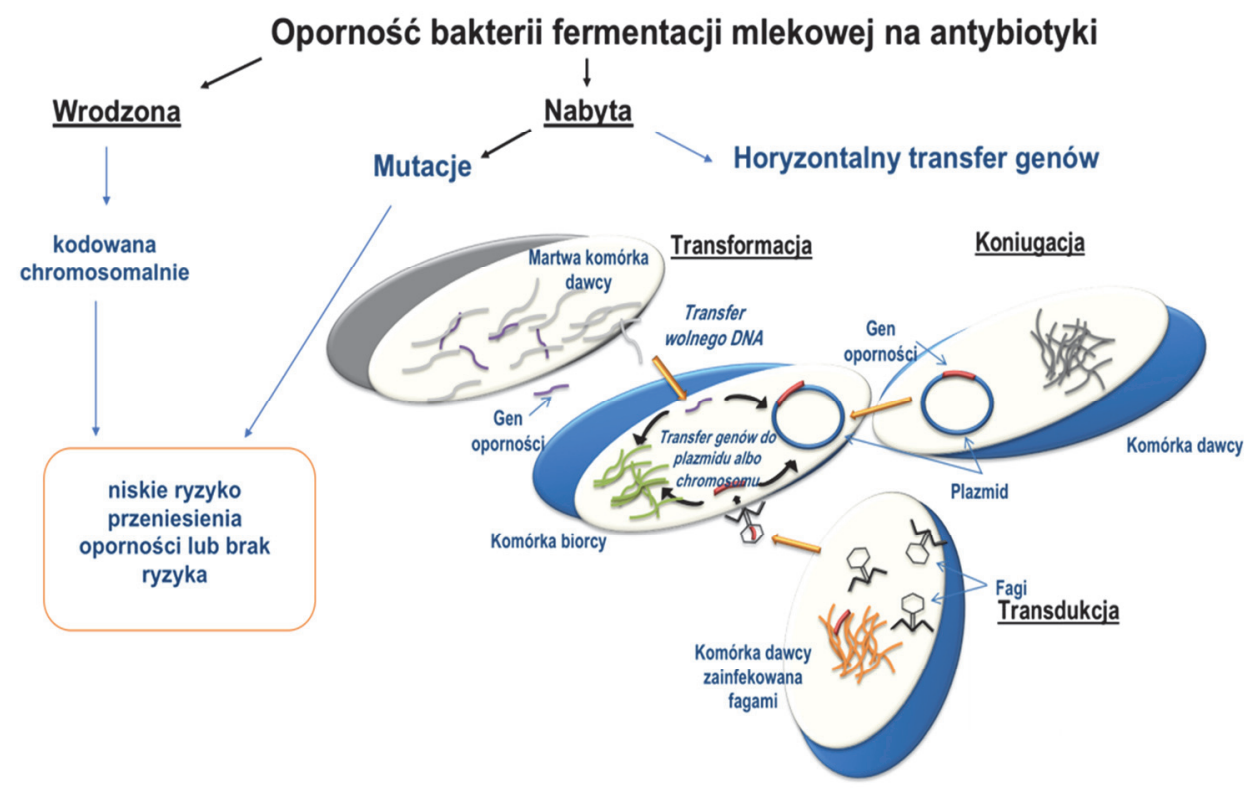

Objaśnienia / Explanatory notes:

Oporność bakterii fermentacji mlekowej na antybiotyki / antibiotic resistance of lactic acid bacteria; wrodzona / intrinsic; nabyta / acquired; kodowana chromosomalnie / chromosomally coded; niskie ryzyko przeniesienia oporności lub brak ryzyka / low risk of resistance transfer or no risk; mutacje / mutations; horyzontalny transfer genów / horizontal gene transfer; transformacja / transformation; koniugacja / conjugation; martwa komórka dawcy / dead donor cell; transfer wolnego DNA / free DNA transfer; gen oporności / resistance gene; transfer genów do plazmidu albo chromosomu / gene transfer to a plasmid or chromosome; komórka biorcy / recipient cell; komórka dawcy / donor cell; plazmid / plasmid; fagi / phages; transdukcja / transduction; komórka dawcy zainfekowana fagami / donor cell infected with phages.

Rys. 1. Mechanizmy oporności LAB na antybiotyki i horyzontalny transfer genów (HGT)

Fig. 1. Mechanisms of LAB antibiotic resistance and horizontal gene transfer (HGT)

Źródło / Source: opracowanie własne / the author's own study

Koniugacja może także zachodzić z udziałem transpozonów. Potocznie zwane są one „skaczącymi genami”. Największą rolę odgrywają transpozony koniugacyjne, które mogą być przekazywane pomiędzy komórkami. Występują w formie zintegrowanej z chromosomem bakteryjnym lub plazmidem. Przekazywanie transpozonów zachodzi podobnie jak plazmidów koniugacyjnych. Transpozon włącza się do genomu w komórce biorcy. Występują one najczęściej w szczepach Lactococcus (Tn5276 i Tn5301), Lactobacillus (Tn916/Tn1545) i Streptococcus (Tn3701) [34]. Najczęściej przenoszone są na nich geny determinujące oporność na tetracykliny, głównie tet( $\mathrm{M})$, chloramfenikol (cat) i kanamycynę (aphA3) [41].

Warunkiem niezbędnym do procesu koniugacji z udziałem plazmidów lub transpozonów jest obecność czynników powodujących agregację komórek przy wysokiej koncentracji mieszaniny dawcy i biorcy. Wytworzenie agregacji, czyli specyficznego 
środowiska, w którym koniugacyjne przekazywanie plazmidów jest ułatwione, jest istotnym warunkiem w środowisku płynnym. Transfer między komórkami przylegającymi do powierzchni wspomagany jest przez białka powierzchniowe [11].

Transfer genów oporności w LAB może także zachodzić na drodze transdukcji $\mathrm{i}$ transformacji. Transdukcja jest procesem polegającym na przenoszeniu materiału genetycznego z komórki do komórki za pośrednictwem bakteriofaga, a więc nie wymaga bezpośredniego kontaktu pomiędzy dawcą i biorcą. Niemniej jednak zarówno transformacja, jak i transdukcja są mechanizmami zdecydowanie rzadziej występującym w LAB niż koniugacja. Jednym z powodów jest udział w koniugacji całego wachlarza mobilnych elementów genetycznych. Istnieje także hipoteza, że koniugacja pozwala na wymianę materiału genetycznego między gatunkami i rodzajami, podczas gdy transformacja i transdukcja ograniczona jest do wymiany materiału genetycznego w obrębie tego samego gatunku [23].

\section{Antybiotykooproność wybranych gatunków bakterii fermentacji mlekowej}

Największą grupą wśród bakterii kwasu mlekowego i prawdopodobnie najpowszechniej stosowaną jako probiotyki w różnych produktach spożywczych są szczepy należące do rodzaju Lactobacillus. Najlepiej scharakteryzowany jest ich fenotyp wynikający z naturalnej (wrodzonej) oporności na wankomycynę należącą do glikopeptydów. Antybiotyk ten wchodzi w kontakt z prekursorami peptydoglikanu po stronie ściany komórkowej błony cytoplazmatycznej i wiąże się z końcem D-alanylo/ D-alaniny pentapeptydu, zapobiegając polimeryzacji prekursorów peptydoglikanu. W kilku gatunkach LAB końcowa reszta D-alaniny jest zastąpiona przez D-mleczan lub D-serynę w muramylopentapeptydzie, zapobiegając wiązaniu wankomycyny [13]. Potwierdzono wrodzoną oporność na wankomycynę takich gatunków, jak Lb. paracasei, Lb. salivarius i Lb. plantarum.

Wśród LAB odnotowano także naturalną oporność na inhibitory syntezy kwasów nukleinowych, takie jak: trimetoprim, a także bacytracynę, ciprofloksacynę, czy kwas fusydowy [3]. Gatunki należące do tego rodzaju wykazują wrażliwość na antybiotyki, których mechanizm działania polega na hamowaniu syntezy ściany komórkowej, m.in. penicylinę i ampicylinę [16]. Są one podatne także na chloramfenikol, erytromycynę i klindamycynę, czyli antybiotyki hamujące syntezę białek [12]. W badaniach prowadzonych na izolatach z produktów mleczarskich wykazano oporność na erytromycynę, tetracyklinę, chloramfenikol i wankomycynę [30, 43, 44]. Ponadto większość badanych szczepów wykazuje oporność na metronidazol, co wynika $\mathrm{z}$ ich naturalnej oporności na sulfonamidy i trimetoprim, podczas gdy zazwyczaj są wrażliwe na piperacylinę oraz piperacylinę $\mathrm{z}$ tazobaktamem. Często obserwowana jest też oporność na aminoglikozydy, jak: neomycyna, kanamycyna, streptomycyna i gentamycyna [12, $15]$. 
Tabela 1. Genetyczne determinanty oporności LAB na antybiotyki

Table 1. Genetic determinants of antibiotic resistance identified in LAB

\begin{tabular}{|c|c|c|c|c|}
\hline $\begin{array}{l}\text { Geny } \\
\text { Genes }\end{array}$ & $\begin{array}{l}\text { Oporność } \\
\text { Resistance }\end{array}$ & $\begin{array}{l}\text { Mechanizm } \\
\text { Mechanism }\end{array}$ & $\begin{array}{l}\text { Lokalizacja } \\
\text { Localisation }\end{array}$ & $\begin{array}{l}\text { Literatura } \\
\text { Literature }\end{array}$ \\
\hline $\begin{array}{c}\operatorname{aac}(6)-\operatorname{aph}(2) \\
\operatorname{ant}(6) \\
\operatorname{aph}(3)-I I I a \\
\end{array}$ & $\begin{array}{l}\text { Aminoglikozydy } \\
\text { Aminoglycosides }\end{array}$ & $\begin{array}{c}\text { modyfikacja } \\
\text { enzymatyczna } \\
\text { enzymatic modyfication }\end{array}$ & - & {$[38]$} \\
\hline blaZ & $\begin{array}{l}\beta \text {-laktamy } \\
\beta \text {-lactams }\end{array}$ & $\begin{array}{l}\text { hydroliza antybiotyku } \\
\text { antibiotic hydrolysis }\end{array}$ & $\begin{array}{l}\text { chromosom } \\
\text { chromosome }\end{array}$ & {$[5]$} \\
\hline cat & $\begin{array}{l}\text { Amfenikole } \\
\text { Amphenicols }\end{array}$ & $\begin{array}{l}\text { hamowanie biosyntezy } \\
\text { białka / inhibition of } \\
\text { protein biosynthesis }\end{array}$ & $\begin{array}{l}\text { plazmid } \\
\text { plasmid }\end{array}$ & {$[26]$} \\
\hline $\begin{array}{l}\operatorname{erm}(\mathrm{A}) \\
\operatorname{erm}(\mathrm{B}) \\
\operatorname{erm}(\mathrm{C}) \\
\operatorname{erm}(\mathrm{T})\end{array}$ & MLS & $\begin{array}{l}\text { metylacja rybosomowa } \\
\text { ribosomal methylation }\end{array}$ & $\begin{array}{l}\text { plazmid, transpozon } \\
\text { chromosom } \\
\text { plazmid, transposon } \\
\text { chromosome }\end{array}$ & {$[26,42]$} \\
\hline $\begin{array}{l}\ln u A \\
\ln u G\end{array}$ & $\begin{array}{l}\text { Linkozamidy } \\
\text { Lincosamide }\end{array}$ & $\begin{array}{c}\text { modyfikacja } \\
\text { enzymatyczna } \\
\text { enzymatic modyfication }\end{array}$ & $\begin{array}{l}\text { plazmid / plasmid } \\
\text { transpozon / transposon }\end{array}$ & {$[39,47]$} \\
\hline$m e f A$ & $\begin{array}{l}\text { Makrolidy } \\
\text { Macrolides }\end{array}$ & efflux & - & {$[10]$} \\
\hline $\operatorname{mrs} C$ & $\begin{array}{l}\text { Makrolidy, linkozaminy, } \\
\text { streptograminy } \\
\text { Macrolides, lincosamides, } \\
\text { streptogramines } \\
\end{array}$ & efflux & - & {$[42]$} \\
\hline $\begin{array}{l}\operatorname{tet}(\mathrm{K}) \\
\operatorname{tet}(\mathrm{L})\end{array}$ & $\begin{array}{l}\text { Tetracykliny } \\
\text { Tetracyclines }\end{array}$ & efflux & plazmid / plasmid & {$[42]$} \\
\hline $\begin{array}{c}\operatorname{tet}(\mathrm{W}) \\
\operatorname{tet}(\mathrm{M}) \\
\operatorname{tet}(\mathrm{S}) \\
\operatorname{tet}(\mathrm{O}) \\
\operatorname{tet}(\mathrm{Q}) \\
\operatorname{tet}(36) \\
\operatorname{tet}(\mathrm{Z})\end{array}$ & $\begin{array}{l}\text { Tetracykliny } \\
\text { Tetracyclines }\end{array}$ & $\begin{array}{l}\text { ochrona rybosomu } \\
\text { ribosom protection }\end{array}$ & $\begin{array}{l}\text { plazmid, transpozon } \\
\text { chromosom } \\
\text { plazmid } \\
\text { transposon } \\
\text { chromosome }\end{array}$ & {$[4,5]$} \\
\hline $\operatorname{vat}(E)$ & $\begin{array}{c}\text { Chinuprystyna- } \\
\text { dalfoprystyna } \\
\text { Quinupristin-dalfopristin }\end{array}$ & $\begin{array}{l}\text { acetylacja antybiotyku } \\
\text { antibiotic acetylation }\end{array}$ & - & {$[37]$} \\
\hline
\end{tabular}

Z kolei oporność nabytą szczepy Lactobacillus najczęściej wykazują na tetracyklinę [31]. Stwierdzono u nich co najmniej 11 różnych genów odpowiedzialnych za oporność na ten antybiotyk, w tym: $\operatorname{tet}(\mathrm{W}), \operatorname{tet}(\mathrm{M}), \operatorname{tet}(\mathrm{S}), \operatorname{tet}(\mathrm{O}), \operatorname{tet}(\mathrm{Q}), \operatorname{tet}(36), \operatorname{tet}(\mathrm{Z})$, tet $(\mathrm{W} / \mathrm{O})$ oraz pompy efflux kodujące geny tet $(\mathrm{K})$ oraz tet $(\mathrm{L})$ [33]. Geny kodujące oporność na chloramfenikol - cat stwierdzano u Lb. acidophilus, Lb. delbrueckii 
subsp. bulgaricus [26], Lb. johnsonii [37], Lb. reuteri oraz Lb. plantarum [1]. Wśród genów kodujących oporność na erytromycynę najczęściej stwierdzanym u Lactobacillus jest gen erm(B), rzadziej pozostałe, takie jak erm(A), erm(C), erm(T) kodujące oporność na makrolidy, linkozamidy i streptograminy (MLS) [37, 44]. Gen erm(B) był stwierdzany m.in. u takich gatunków jak $L b$. fermentum, $L b$. vaginalis, $L b$. plantarum, Lb. salivarius, Lb. acidophilus, Lb. animalis i $S$. thermophilus. Wśród genów kodujących oporność na antybiotyki aminoglikozydowe dominują aac(6)-aph(2), ant(6) i aph(3)-IIIa [38]. Często stwierdza się także geny kodujące oporność na linkozamidy $\operatorname{lnu}(\mathrm{A})$ i $\operatorname{lnu}(\mathrm{G})[26,29,39,47]$. Z kolei za oporność na streptograminy odpowiada najczęściej gen vat(E) [37] (tab. 1).

W szczepach bakterii probiotycznych stwierdzano m.in. obecność genów erm(B) i/lub tet( $(\mathrm{W}), \operatorname{tet}(\mathrm{M})$ [30]. Geny oporności $\operatorname{tet}(\mathrm{W})$ i $\operatorname{lnu}(\mathrm{A})$ stwierdzono m.in. w komercyjnym szczepie probiotycznym $L b$. reuteri ATCC 55730 [29]. Ponadto Hummel i wsp. [26] w szczepie probiotycznym Lb. salivarius BFE 7441 stwierdzili obecność genu erm(B) na chromosomie. W innych badaniach dowiedziono, że probiotyczny szczep Lb. plantarum CCUG 43738 wykazywał fenotypową oporność na tetracyklinę i minocyklinę, stwierdzono także obecność tet(S) na plazmidzie [27].

Pałeczki należące do rodzaju Bifidobacterium sp. charakteryzują się wrażliwością na ampicylinę, cefotaksym i erytromycynę. Natomiast oporność przy wysokich wartościach MIC stwierdzono wobec streptomycyny i gentamycyny [35]. Szczepy izolowane z żywności wykazywały oporność na aminoglikozydy, cykloserynę, kwas nalidyksowy i oporność na kanamycynę, polimyksynę B oraz aztreonam [14]. Bifidobakterie są też naturalnie oporne na mupirocynę oraz duże stężenia aminoglikozydów [36, 40].

W szczepach Bifidobacterium (B. animalis subsp. lactis i B. thermophilum) zidentyfikowano m.in. gen kodujący białko zabezpieczające rybosom oraz transpozon Tn5454 [43]. Często obserwowana oporność rodzaju Bifidobacterium na tetracyklinę kodowana jest zazwyczaj przez geny $\operatorname{tet}(\mathrm{W}), \operatorname{tet}(\mathrm{M}), \operatorname{tet}(\mathrm{O}), \operatorname{tet}(\mathrm{W} / 32 / \mathrm{O}) \mathrm{i} \operatorname{tet}(\mathrm{O} / \mathrm{W})$, co stwierdzono u kilku gatunków Bifidobacterium, w tym B. longum (subsp. infantis i subsp. longum), B. breve, B. animalis subsp. lactis, B. bifidum, B. pseudocatenulatum i $B$. thermophilum $[2,3,19,24,43]$. Gen tet(W) oznaczono w szczepach $B$. longum i we wszystkich szczepach $B$. animalis subsp. lactis $[2,3,24]$ izolowanych z fermentowanych produktów mlecznych. Wiele z wyżej wymienionych determinant genetycznych występuje na ruchomych elementach, takich jak transpozony i plazmidy, które mogą rozprzestrzeniać geny oporności na antybiotyki głównie za pomocą mechanizmów koniugacyjnych.

$\mathrm{W}$ porównaniu z liczbą doniesień dotyczących antybiotykooporności bakterii $\mathrm{z}$ rodzaju Lactobacillus, informacji na temat Lactococcus jest stosunkowo niewiele. Może to wynikać z faktu, że spośród wszystkich gatunków należących do rodzaju Lactococcus jedynie L. lactis subsp. lactis i L. lactis subsp. cremoris mają zastosowanie 
w przemyśle spożywczym. Dane literaturowe wskazują, że bakterie z rodzaju Lactococcus wykazują naturalną oporność na metronidazol, trimetoprim, gentamycynę i kanamycynę [20]. Wrażliwe są z kolei na rifampicynę, chloramfenikol, antybiotyki $\beta$-laktamowe oraz erytromycynę, wankomycynę, linkomycynę i teikoplaninę [17]. Najczęściej wskazywana jest oporność na tetracykliny, kodowana głównie przez gen tet(M). Stwierdza się także obecność szczepów opornych na erytromycynę, za co odpowiedzialny jest gen erm(B) [18]. W literaturze znajdują się także pojedyncze doniesienia dotyczące oporności Lactococcus na inne antybiotyki, na przykład trimetoprim, za co odpowiedzialny jest gen $d f r$ A, rifampicynę, czy kloksacylinę. Na podstawie analizy danych literaturowych można stwierdzić, że antybiotykooporność szczepów Lactococcus nie jest powszechnie występującym problemem.

Biorąc pod uwagę, że niektóre szczepy należące do rodzaju Enterococcus są zaliczane do patogenów oportunistycznych, nadal dyskusyjne jest ich stosowanie jako probiotyków u ludzi. Dotychczas jedynie gatunek E. faecium znalazł zastosowanie jako probiotyk i to głównie dla zwierząt. Paciorkowce z rodzaju Enterococcus charakteryzują się opornością wrodzoną na: cefalosporyny (wszystkich generacji), trimetoprim/sulfametoksazol, linkozamidy (klindamycynę), małe stężenia aminoglikozydów [25]. Za szczególnie niebezpieczną uważa się oporność enterokoków na wankomycynę, która jest lekiem ostatniej szansy w zakażeniach enterokokowych. U enterokoków, w odróżnieniu od szczepów należących do rodzaju Lactobacillus, oporność na wankomycynę jest cechą nabytą, kodowaną na mobilnych elementach genetycznych. Pod względem oporności na wankomycynę enterokoki charakteryzują się dużą niejednorodnością zarówno fenotypową, jak i genotypową. Szczepy wytwarzające prekursory peptydoglikanu kończące się dipeptydem D-Ala-D-Lac wykazują oporność na duże stężenia wankomycyny i teikoplaniny, natomiast zakończone D-Ala-D-Ser - jedynie na małe stężenia wankomycyny [13]. Ze względu na szybkość oraz częstość rozprzestrzeniania się największe znaczenie mają fenotypy VanA i VanB, których geny zlokalizowane są na ruchomych elementach genetycznych. Fenotyp VanA indukowany przez wankomycynę i teikoplaninę charakteryzuje enterokoki oporne na duże stężenia tych antybiotyków. Przenoszenie genów vanA odbywa się przez transpozon Tn1546 znajdujący się na plazmidzie lub fragmencie chromosomu. Paciorkowce z rodzaju Enterococcus o fenotypie VanB wykazują oporność na różne stężenia wankomycyny oraz wrażliwość na teikoplainę. Induktorem tego fenotypu jest wyłącznie wankomycyna. Geny vanB przekazywane są między komórkami drobnoustrojów za pomocą dużych koniugacyjnych elementów genetycznych, takich jak transpozon: Tn1549, Tn 1547, Tn5382, które mogą być przenoszone między chromosomami [22].

Mobilne elementy genetyczne mogą być przenoszone między szczepami bakterii fermentacji mlekowej do komórek innych bakterii Gram-dodatnich, a także Gramujemnych. Oprócz transferu wewnątrzgatunkowego stwierdza się także możliwość 
przekazywania genów szczepom Lactobacillus, Staphylococcus, Bacillus subtilis, Escherichia coli, a nawet Listeria monocytogenes [34]. Z drugiej strony, pałeczki kwasu mlekowego są w stanie pozyskać determinanty oporności od innych bakterii Gramdodatnich [23]. Poza badaniami in vitro, potencjalne ryzyko związane z możliwością transferu genów od LAB wykazano również na eksperymentalnych modelach zwierzęcych [33]. Wszystkie te badania potwierdzają hipotezę, że wprowadzanie do przewodu pokarmowego $\mathrm{LAB}$, będących rezerwuarami genów kodujących oporność na antybiotyki, stwarza ryzyko przeniesienia tych genów do mikroflory jelitowej.

Oporność bakterii fermentacji mlekowej na antybiotyki może być związana także z mutacjami chromosomalnymi. W bakteriach szczepu L. rhamnosus zidentyfikowano m.in. mutację genu 23S rRNA zmniejszającą powinowactwo erytromycyny do rybosomu [18]. Mutacje są jednak bardzo rzadko związane z możliwością przeniesienia oporności pomiędzy szczepami [9].

\section{Analizy molekularne, sekwencjonowanie genów i analiza bioinformatyczna w badaniach antybiotykooporności LAB}

Zastosowanie metod molekularnych, takich jak analiza mikromacierzy czy inne techniki molekularne jest niezwykle pomocne w określaniu podstaw genetycznych nabytych fenotypów oporności. Co więcej, rosnąca dostępność sekwencji genomowych i redukcja kosztów urządzeń do sekwencjonowania genomu stwarzają nowe możliwości badań przesiewowych genów oporności na antybiotyki [7].

W ostatnim roku pojawiła się praca zespołu badaczy z Włoch i Irlandii, w której autorzy - Campedelli i wsp. [8] ustalili wzorce wrażliwości na antybiotyki 182 szczepów z rodzaju Lactobacillus i porównali ich fenotypy z genotypami na podstawie sekwencjonowania całego genomu. Zaskakujące było to, że wiele gatunków wykazywało poziom oporności na antybiotyki przekraczający poziom zalecany przez EFSA. Autorzy zasugerowali, że wartości definiujące MIC powinny zostać ponownie zweryfikowane. Dostarczyli tym samym dowodów na konieczność zmian wytycznych regulacyjnych dotyczących oceny bezpieczeństwa szczepów probiotycznych.

Wartości MIC dla szczepów LAB definiuje EFSA. Gdy MIC obserwowany u szczepu probiotycznego jest wyższy niż zdefiniowana wartość graniczna, wówczas należy przeprowadzić badania genetyczne celem oznaczenia obecności genów antybiotykooporności. Powinna to być praktyka bezwzględna, zanim probiotyk będzie można bezpiecznie stosować w żywności. Nie ma jednak standardów dotyczących wykrywania i identyfikacji genów oporności na antybiotyki ani standardów badania możliwości ich transferu między różnymi izolatami i gatunkami. Dzieje się tak dlatego, że geny oporności są liczne, co utrudnia standaryzację metod, a ich wykrywanie wymaga izolatów referencyjnych i sekwencji genów, które nadal są nieliczne lub niekompletne. 
Postępy w technologiach sekwencjonowania nowej generacji umożliwiają sekwencjonowanie całego genomu oraz śledzenie powstawania zmian w populacji i analizowanie różnic genomicznych między osobnikami w obrębie populacji pod różnymi presjami selekcyjnymi lub środowiskami [6, 32]. Zsekwencjonowanie genomu szczepu referencyjnego pozwala na wykrycie mutacji poprzez porównanie sekwencji badanych izolatów poddanych stresom środowiskowym z sekwencją szczepów referencyjnych. Zhang i wsp. [46] zbadali mechanizmy oporności na streptomycynę probiotycznego szczepu L. plantarum ATCC 14917. Autorzy pasażowali szczep w podłożach ze zwiększającym się stężeniem streptomycyny. Po 25 dniach osiągnięto minimalne stężenie hamujące (MIC) o 8,192 razy wyższe niż MIC pierwotnego izolatu macierzystego L. plantarum ATCC 14917. Następnie z zastosowaniem sekwencjonowania zbadano mechanizmy adaptacji i odporności tego szczepu. U opornego mutanta stwierdzono mutacje w 5 genach związanych z białkiem rybosomalnym S12, białkiem LPXTG, białkiem rodziny LrgA, białkiem rodziny fosfatazy Ser/Thr i hipotetycznym białkiem, które może korelować z opornością na streptomycynę. Po pasażu w pożywce wolnej od streptomycyny pozostał tylko zmutowany gen kodujący rybosomalne białko S12. Chociaż wartość MIC L. plantarum ATCC 14917 była zmniejszona przy braku presji selekcyjnej pozostawała 128-krotnie wyższa niż wartość MIC macierzystego izolatu, wskazując, że białko rybosomalne S12 może odgrywać ważną rolę w oporności na streptomycynę. Badania te wskazują, że zamiast badać transfer genów za pomocą metod in vivo lub in vitro, skutecznym sposobem kompleksowej oceny potencjalnych genów oporności na antybiotyki i ich mobilności szczepów probiotycznych może być sekwencjonowanie całego genomu i analiza bioinformatyczna.

\section{Podsumowanie}

Bakterie fermentacji mlekowej, w tym szczepy probiotyczne, mogą stanowić rezerwuar genów oporności na antybiotyki. W związku z niebywałą zdolnością tej grupy drobnoustrojów do wymiany materiału genetycznego niezbędne jest ciągłe monitorowanie nie tylko fenotypu, ale także genotypu oporności oraz określanie lokalizacji determinant oporności i możliwości ich przekazywania w warunkach in vivo.

Publikacja zostata napisana $w$ wyniku odbywania przez autorki stażu $w$ Państwowym Instytucie Weterynaryjnym w Puławach, wspófinansowanego przez Unie Europejska w ramach Europejskiego Funduszu Społecznego (Program Operacyjny Wiedza Edukacja Rozwój), zrealizowanego w projekcie Program Rozwojowy Uniwersytetu Warmińsko-Mazurskiego w Olsztynie (POWR.03.05.00-00-Z310/17). 


\section{Literatura}

[1] Ahn C., Collins-Thompson D., Duncan C., Stiles M.E.: Mobilization and location of the genetic determinant of chloramphenicol resistance from Lactobacillus plantarum caTC2R. Plasmid, 1992, 27, 169-176.

[2] Aires J., Doucet-Populaire F., Butel M.J.: Tetracycline resistance mediated by tet(W), tet(M), and tet(O)genes of Bifidobacterium isolates from humans. Appl. Environ. Microbiol., 2007, 73, 27512754.

[3] Ammor M.S., Flórez A.B., Alvarez-Martin P., Margolles A., Mayo B.: Analysis of tetracycline resistance tet(W) genes and their flanking sequences in intestinal Bifidobacterium species. J. Antimicrob. Chemother., 2008, 62, 688-693.

[4] Ammor M.S., Gueimonde M., Danielsen M., Zagorec M., van Hoek A.H., de los Reyes-Gavilán C.G.: Two different tetracycline resistance mechanisms, plasmid-carried tet(L) and chromosomally located transposon-associated tet(M), coexist in Lactobacillus sakei Rits 9. Appl. Environ. Microbiol., 2008, 74, 1394-1401.

[5] Aquilanti L., Garofalo C., Osimani A., Silvestri G., Vignaroli C., Clementi F.: Isolation and molecular characterization of antibiotic-resistant lactic acid bacteria from poultry and swine meat products. J. Food Prot., 2007, 70, 557-565.

[6] Barrick J.E., Lenski R.E.: Genome dynamics during experimental evolution. Nature Rev. Genet., 2013, 14, 827-839.

[7] Bennedsen M., Stuer-Lauridsen B., Danielsen M., Johansen, E.: Screening for antimicrobial resistance genes and virulence factors via genome sequencing. Appl. Environ. Microbiol., 2011, 77, 2785-2787.

[8] Campedelli I., Mathur H., Salvetti E., Clarke S., Rea M.C., Torriani S., Ross R.P, Hill C., O'Toole P.W.: Genus-wide assessment of antibiotic resistance in Lactobacillus spp. Appl. Environ. Microbiol., 2018, 85(1), \#e01738-18. DOI: 10.1128/AEM.01738-18.

[9] Cannon J.P., Lee T.A., Bolanos J.T., Danziger L.H.: Pathogenic relevance of Lactobacillus: A retrospective review of over 200 cases. Eur. J. Clin. Microbiol. Infect. Dis., 2005, 24, 31-40.

[10] Cauwerts K., Pasmans F., Devriese L.A., Martel A., Haesebrouck F., Decostere A.: Cloacal Lactobacillus isolates from broilers show high prevalence of resistance towards macrolide and lincosamide antibiotics. Avian Pathol., 2006, 35, 160-164.

[11] Clewell D.B., Francia M.V., Flannagan S.E., An F.Y.: Enterococcal plasmid transfer: Sex pheromones, transfer origins, relaxases, and the Staphylococcus aureus issue. Plasmid, 2002, 48, 193-201.

[12] Coppola R., Succi M., Tremonte P., Reale A., Salzano G., Sorrentino E.: Antibiotic susceptibility of Lactobacillus rhamnosus strains isolated from Parmigiano Reggiano cheese. Le Lait, 2005, 85, 193204.

[13] Courvalin P.: Genetics of glycopeptide resistance in Gram-positive pathogens. Int. J. Med. Microbiol., 2005, 294, 479-486.

[14] D'Aimmo M.R., Modesto M., Biavati B.: Antibiotic resistance of lactic acid bacteria and Bifidobacterium spp. isolated from dairy and pharmaceutical products. Int. J. Food Microbiol., 2007, 115, 3542.

[15] Danielsen M.: Characterization of the tetracycline resistance plasmid pMD5057 from Lactobacillus plantarum 5057 reveals a composite structure. Plasmid, 2002, 48, 98-103.

[16] Danielsen M., Wind A.A.: Susceptibility of Lactobacillus spp. to antimicrobial agents. Int. J. Food Microbiol., 2003, 82, 1-11.

[17] Devirgiliis C., Barile S., Caravelli A., Coppola D., Perozzi G.: Identification of tetracycline- and erythromycin-resistant Gram-positive cocciwithin the fermentingmicroflora of an Italian dairy food product. J. Appl. Microbiol., 2010, 109, 313-323. 
[18] Flórez A.B., Ladero V., Alvarez-Martín P., Ammor M.S., Alvarez M.A., Mayo B.: Acquired macrolide resistance in the human intestinal strain Lactobacillus rhamnosus E41 associated with a transition mutation in 23S rRNA genes. Int. J. Antimicrob. Agents., 2007, 30, (4), 341-344.

[19] Flórez A.B., Ammor M.S., Alvarez-Martín P., Margolles A., Mayo B.: Molecular analysis of tet(W)gene-mediated tetracycline resistance in dominant intestinal Bifidobacterium species from healthy humans. Appl. Environ. Microbiol., 2006, 72, 7377-7379.

[20] Florez A.B., Delgado S., Mayo B.: Antimicrobial susceptibility of lactic acid bacteria isolated from a cheese environment. Canadian J. Microbiol., 2005, 51, 51-58.

[21] Franz C., Stiles M.E., Schleifer K.H., Holzapfel W.H.: Enterococci in foods-a conundrum for food safety. Int. J. Food Microbiol., 2003, 88 (2-3), 105-122.

[22] Gholizadeh Y., Courvalin P.: Acquired and intrinsic glycopeptide resistance in enterococci. Int. J. Antimicrob. Agents, 2000, 16 (Supl. 1), S11-S17.

[23] Gueimonde M., Sanchez B.G., de Los Reyes-Gavilán C., Margolles A.: Antibiotic resistance in probiotic bacteria. Front Microbiol., 2013, 4, 202.

[24] Gueimonde M., Flórez A.B., van Hoek A.H., Stuer-Lauridsen B., Strøman P., de los Reyes-Gavilán C.G.: Genetic basis of tetracycline resistance in Bifidobacterium animalis subsp. lactis. Appl. Environ. Microbiol., 2010, 76, 3364-3369.

[25] Hollenbeck B.L., Rice L.B.: Intrinsic and acquired resistance mechanisms in enterococcus. Virulence, 2012, 3 (5), 421-569.

[26] Hummel A.S., Hertel C., Holzapfel W.H., Franz C.M.: Antibiotic resistances of starter and probiotic strains of lactic acid bacteria. Appl. Environ. Microbiol., 2007, 73, 730-739.

[27] Huys G., Vancanneyt M., D'Haene K., Vankerckhoven V., Goossens H., Swings J.: Accuracy of species identity of commercial bacterial cultures intended for probiotic or nutritional use. Research in Microbiology, 2006, 157, 803-810.

[28] Jensen L.B., Garcia-Migura L., Valenzuela A.J.S., Løhr M., Hasman H., Aarestrup F.M.: A classification system for plasmids from enterococci and other Gram-positive bacteria. J. Microbiol. Methods, 2010, 80, 25-43.

[29] Kastner S., Perreten V., Bleuler H., Hugenschmidt G., Lacroix C., Meile L.: Antibiotic susceptibility patterns and resistance genes of starter cultures and probiotic bacteria used in food. System. Appl. Microbiol., 2006, 29, 145-155.

[30] Klare I., Konstabel C., Werner G., Huys G., Vankerckhoven V., Kahlmeter G.: Antimicrobial susceptibilities of Lactobacillus, Pediococcus and Lactococcus human isolates and cultures intended for probiotic or nutritional use. J. Antimicrob. Chemoth., 2007, 59, 900-912.

[31] Korhonen J.M., Danielsen M., Mayo B., Egervarn H., Axelsson L., Huys G., von Wright A.: Antimicrobial susceptibility and proposed microbiological cut-off values of lactobacilli by phenotypic determination. Int. J. Probiot. Prebiot., 2008, 3, 257-268.

[32] Lenski R.E.: Experimental evolution and the dynamics of adaptation and genome evolution in microbial populations. ISME, 2017, 11 (10), 2181-2194.

[33] Mater D.D., Langella P., Corthier G., Flores M.J.: A probiotic Lactobacillus strain can acquire vancomycin resistance during digestive transit in mice. J. Mol. Microbiol. Biotechnol., 2008, 14, 123127.

[34] Mathur S., Singh R.: Antibiotic resistance in food lactic acid bacteria - a review. Int. J. Food Microbiol., 2005, 105, 281-295.

[35] Mättö J., Alakomi H.L., Vaari A., Virkajärvi I., Saarela M.: Influence of processing conditions on Bifidobacterium animalis subsp. lactis functionality with a special focus on acid tolerance and factors affecting it. Int. Dairy J., 2006, 16, 1029-1037.

[36] Mayrhofer S., Mair C., Kneifel W., Domig K.J.: Susceptibility of bifidobacteria of animal origin to selected antimicrobial agents. Chemoth. Res. Practice, 2011, \#989520. DOI: 10.1155/2011/989520. 
[37] Mayrhofer S., van Hoek A.H.A.M., Mair C., Huys G., Aarts H.J.M., Kneifel W., Domig K.J.: Antibiotic susceptibility of members of the Lactobacillus acidophilus group using broth microdilution and molecular identification of their resistance determinants. Int. J. Food Microbiol., 2010, 144, 8187.

[38] Rojo-Bezares B., Sáenz Y., Poeta P., Zarazaga M., Ruiz-Larrea F., Torres C.: Assessment of antibiotic susceptibility within lactic acid bacteria strains isolated from wine. Int. J. Food Microbiol., 2006, 111, 234-240.

[39] Rosander A., Connolly E., Roos S.: Removal of antibiotic resistance gene-carrying plasmids from Lactobacillus reuteri ATCC 55730 and characterization of the resulting daughter strain, L. reuteri DSM 17938. Appl. Environ. Microbiol., 2008, 74(19), 6032-6040.

[40] Serafini F., Bottacini F., Viappiani A., Baruffini E., Turroni F., Foroni E., Lodi T., van Sinderen D., Ventura M.: Insights into physiological and genetic mupirocin susceptibility in bifidobacteria. Appl. Environ. Microbiol., 2011, 77, 3141-3146.

[41] Teuber M., Meile L., Schwarz F.: Acquired antibiotic resistance in lactic acid bacteria from food. Antonie Van Leeuwenhoek, 1999, 76, 115-137.

[42] Thumu S.C., Halami P.M.: Presence of erythromycin and tetracycline resistance genes in lactic acid bacteria from fermented foods of Indian origin. Antonie Van Leeuwenhoek, 2012, 102, 541-551.

[43] Van Hoek A.H., Mayrhofer S., Domig K.J., Aarts H.J.: Resistance determinant erm(X) is borne by transposon Tn5432 in Bifidobacterium thermophilum and Bifidobacterium animalis subsp. lactis. Int. J. Antimicrob. Agents, 2008, 31, 544-548.

[44] Van Hoek A.H., Mayrhofer S., Domig K.J., Flórez A.B., Ammor M.S., Mayo B., Aarts H.J.M.: Mosaic tetracycline resistance genes and their flanking regions in Bifidobacterium thermophilum and Lactobacillus johnsonii. Antimicrob. Agents Chemoth., 2008, 52, 248-252.

[45] Werner G., Coque T.M., Franz C.M., Grohmann E., Hegstad K., Jensen L., van Schaik W., Weaver K.: Antibiotic resistant enterococci-tales of a drug resistance gene trafficker. Int. J. Med. Microbiol., 2013, 303 (6-7), 360-379.

[46] Zhang J., Gao B., Wang D., Huo Z., Wang J., Zhang J., Shao Y.: Whole-genome sequencing reveals the mechanisms for evolution of streptomycin resistance in Lactobacillus plantarum. J. Dairy Sci., 2018, 101, 2867-2874.

[47] Zhu X.Q., Wang X.M., Li H., Shang Y.H., Pan Y.S., Wu C.M., Wang Y., Du X.D., Shen J.Z.: Novel $\ln u(\mathrm{G})$ gene conferring resistance to lincomycin by nucleotidylation, located on Tn6260 from Enterococcus faecalis E531. J. Antimicrob. Chemoth., 2017, 72, 4, 993-997.

\section{LACTIC ACID BACTERIA INCLUDING PROBIOTIC STRAINS AS A RESERVOIR OF ANTIBIOTIC RESISTANCE GENES}

S u m m a r y

Antibiotic resistance has become one of the major issues pertaining to public health safety. For a long time the phenomenon of bacterial resistance to antibiotics has been associated exclusively with selective pressure in the hospital environment. It was only the increasing knowledge of the genetic basis of resistance and the mechanisms accompanying its transmission that shifted the focus of researchers to comprehensively approach its epidemiology. Lactic acid bacteria (LAB) have been recognised as safe with the GRAS (Generally Recognized as Safe) and QPS (Qualified Presumption of Safety) status granted by FDA and EFSA. However, the recently conducted studies have shown that among the strains of the starter cultures and probiotic strains, there are also those resistant to antibiotics, which can transmit their antibiotic resistance to other microorganisms. If the resistance is innate, associated with information encoded in 
the chromosome, it is not a cause for concern. Unfortunately, increasingly often, there are reported strains with the so-called acquired resistance resulting from the spot mutations or gene transfer. As a consequence those two phenomena lead to permanent resistance inheritance and to its propagation by horizontal gene transfer (HGT). Owing to that gene transfer, in cells appear new resistance genes, which are transferred on mobile genetic elements, such as plasmids, transposons and insertion sequences. More and more worrying reports appear, which indicate that $\mathrm{LAB}$ including probiotic strains exhibit the acquired resistance to a growing number of antibiotic groups, especially to tetracyclines, macrolides, glycopeptides and amphenicols. A number of those strains have been found to contain determinants of resistance on mobile genetic elements and their ability has been confirmed to transfer genes by HGT to other bacteria including pathogens.

Key words: antibiotic resistance, LAB, probiotics, horizontal gene transfer 